\title{
PRODUCTION OF CYPRIPEDIUM MONTANUM SEEDLINGS FOR COMMERCIAL VALUE AND REINTRODUCTION INTO RESTORATION PROJECTS: PHASE II
}

\author{
Roger H. Smith ${ }^{1}$, Jane A. Smith \& Scott Liebler \\ Kelsey Creek Laboratories, 13206 - 233rd Avenue SE, Issaquah WA 98027. U.S.A. \\ 1Author for correspondence: kelseycreeklabs@comcast.net
}

The mountain lady's slipper (Cypripedium montanum Douglas ex Lindl. is a large and charismatic perennial orchid once widely distributed in montane regions of the northwestern United States. This native North American orchid is a member of a genus that has been highly prized by collectors worldwide. Cypripedium is now among the most endangered plant genera in the world. As evidence of threats to its survival, a decade ago

Cypripedium was the sole plant genus the World Wildlife Fund placed on its "10 most wanted" list. Also, the accumulative evidence for progressive global warming is a threat to this genus and other temperate terrestrial orchids worldwide. Its survival will continue to be jeopardized unless measures are taken to ensure its persistence. Until recently, mountain lady's slipper seeds were very difficult to germinate in the laboratory.

Through efforts at Kelsey Creek Laboratories (KCL) in 2004, a method was developed to germinate immature seeds at a high frequency and resulting protocorms are now being routinely cultured in the laboratory (Phase I USDA-Small Business Innovative Research Grant \# 2004-33610-14304). KCL is collab- orating with Andy Huber at GROWISER (Grande Ronde Overlook Wildflower Institute Serving Ecological Restoration) preserve and Nan Vance and Daniel 1. Luoma at Oregon State University in Corvallis to better understand this orchid's growth patterns in the laboratory and field, interaction with mycorrhizae, and exploring other methods of culturing and preserving this species, such as cloning, cryogenics, and synthetic seed production.

The GROWISER preserve has a few thousand C. montanum plants that are being tracked from year to year for plant growth, flower and seed production. In addition, the preserve is being used to measure results of restoration capabilities of laboratory-raised seedlings.

Kelsey Creek Laboratories is presently comparing agar-based and liquid-based seed germination of $C$. montanum, and also exploring the feasibility of cloning this species for commercial value. Preliminary results of these studies and others will be included in the poster presentation. This Phase II research is supported by United States Department of Agriculture-Small Business Innovative Research Grant 2005-03191.

Roger H. Smith,, PhD, and Jane A. Smith PhD, are co-owners of Kelsey Creek Laboratories, a custom orchid laboratory serving orchid nurseries and hobbyists through seed germination and mericloning. They have been in business for eleven years. In addition, they have a research project on Cypripedium montanum, a mountain lady's slipper, a threatened species in the Pacific Northwest of USA and Canada. The research has been supported by two consecutive grants from the US Department of Agriculture-Small Business Innovative Research (USDA-SBIR) program. Kelsey Creek Laboratories is evolving toward focusing more on threatened and endangered terrestrial orchids of temperate climates.

Scott Liebler, BS, ia a technician at Kelsey Creek Laboratories and focuses primarily on mycorrhizae and terrestrial orchid seed and seedling interactions. 